\title{
Determinan Kejadian Pre Eklampsia Pada Ibu Bersalin Di RSIA Dr. Djoko Pramono Karawang Jawa Barat Tahun 2019
}

\author{
Nurhayati \\ Universitas Respati Indonesia \\ E-mail : nuradzkadiina@gmail.com
}

\begin{abstract}
Abstrak
Preeklampsia adalah penyakit dengan tanda -tanda hipertensi, edema, dan proteinuria yang timbul karena kehamilan. Penyakit ini umunya terjadi dalam triwulan ke -3 kehamilan, tetapi dapat terjadi sebelumnya, misalnya pada mola hidatidosa (Saifuddin, 2006) . Kejadian Pre eklampsia diperkirakan sebesar 3-10\% dari seluruh kehamilan. Hasil studi pendahuluan yang dilakukan, didapatkan jumlah kasus PEB di RSIA dr. Djoko Pramono Karawang Jawa Barat Tahun 2019 sebanyak 8,27\%. Tujuan Penelitian adalah Diketahui determinan kejadian Pre eklampsia pada ibu bersalin di RSIA dr. Djoko Pramono Karawang Jawa Barat Tahun 2019. Rancangan penelitian Cross Sectional, sampel dalam penelitian ini berjumlah 376 responden. Analisis dilakukan secara univariate, bivariate menggunakan chi square dan multivariate menggunakan regresi logistic ganda. Variabel yang berhubungan dengan kejadian Pre eklampsia pada ibu bersalin adalah usia $(p=0,000)$, pendidikan $(p=0,000)$, pekerjaan $(p=0,009)$, riwayat hipertensi $(p=0,000)$, riwayat $D M(p=0,000)$ dan pemeriksaan ANC $(p=0,000)$, sedangkan variabel yang tidak berhubungan adalah paritas $(p=0,141)$. Variabel yang dominan berhubungan dengan kejadian BBLR pada ibu bersalin adalah pemeriksaan ANC dengan Odds ratio (OR) 15,6. Pihak Rumah Sakit Meningkatkan pemeriksaan kehamilan (antenatal care) secara berkala minimal 4 kali selama kurun kehamilan dan dimulai sejak umur kehamilan muda . Ibu hamil yang memiliki faktor risiko pre eklampsia harus cepat dilaporkan, dipantau dan dirujuk pada institusi pelayanan kesehatan yang lebih tinggi
\end{abstract}

Kata Kunci : Pre eklampsia, antenatal care

\begin{abstract}
Preeclampsia is a disease with signs of hypertension, edema and proteinuria arising from pregnancy. This disease generally occurs in the 3rd trimester of pregnancy, but can occur earlier, for example in hydatidiform moles (Saifuddin, 2006). The incidence of pre-eclampsia is estimated at 3$10 \%$ of all pregnancies. The results of the preliminary study conducted showed that the number of PEB cases at dr. Djoko Pramono Karawang Hospital, West Java in 2019 was $8.27 \%$. The purpose of the study was to know the determinants of the incidence of Pre-eclampsia in mothers who gave birth at dr. Djoko Pramono Karawang Hospital, West Java in 2019. Cross sectional research design, the sample in this study amounted to 376 respondents. The analysis was performed univariate, bivariate using chi square and multivariate using multiple logistic regression. The variables associated with the incidence of pre-eclampsia in labor mothers were age $(p=0,000)$, education $(p=0,000)$, occupation $(p=0.009)$, history of hypertension $(p=0,000)$, history of diabetes $(p=0,000)$ and ANC examination.

http://ejournal.urindo.ac.id/index.php/kesehatan
\end{abstract}

Article History :

Sumbitted 03 Juni 2021, Accepted 29 Juni 2021, Published 30 Juni 2021 
$(p=0.000)$, while the unrelated variable was parity $(p=0.141)$. The dominant variable associated with the incidence of LBW in maternal delivery was ANC examination with an odds ratio (OR) of 15.6. The Hospital Increase antenatal care (antenatal care) at least 4 times during pregnancy and starting at a young gestational age. Pregnant women who have risk actors who give preeclampsia must be quickly reported, monitored and referred to a highfer health service institution

Keyword : Preeclampsia, antenatal care 


\section{PENDAHULUAN}

Didapatkan data lebih dari 4 juta wanita hamil setiap tahun mengalami pre eklampsia dan diperkirakan sebanyak 50.000 sampai 70.000 wanita meninggal karena pre eklampsia serta 500.000 bayi meninggal setiap tahunnya. Hampir diseluruh dunia Pre eklampsia merupakan penyebab $15-20 \%$ kematian wanita serta penyebab utama mortalitas dan morbiditas pada janin (Raghupathy, 2013) . Indonesia adalah salah satu negara berkembang yang memiliki Angka Kematian Ibu (AKI) dan kematian perinatal tinggi yaitu tertinggi ketiga di ASEAN dan tertinggi kedua di kawasan South East Asian Nation Regional Organization (WHO, 2013) .

Pada Survei Demografi dan Kesehatan Indonesia (SDKI) tahun 2017 didapatkan AKI di 305 per $100.000 \mathrm{KH}$. Angka tersebut jauh dari yang diharapkan dari target Rencana Pembangunan Jangka Menengah Nasional (RPJMN) tahun 2010-2014 yaitu AKI sebesar 118 per $100.000 \mathrm{KH}$, target MDG's (Millenium Development Goals) tahun 2015 yaitu 102 per $100.000 \mathrm{KH}$ sedangkan target SDG's (Sustainable Development Goals) tahun 2030 yaitu AKI 70/100.000 KH (Kemenkes RI, 2015) .

Preeklampsia adalah penyakit dengan tanda -tanda hipertensi, edema, dan proteinuria yang timbul karena kehamilan. Penyakit ini umumnya terjadi dalam triwulan ke -3 kehamilan, tetapi dapat terjadi sebelumnya, misalnya pada mola hidatidosa (Saifuddin, 2006) . Kejadian Pre eklampsia diperkirakan sebesar 3-10\% dari seluruh kehamilan. Berdasarkan data dari WHO menunjukan bahwa Hipertensi menyebabkan $16 \%$ dari seluruh angka kematian ibu di negara berkembang, 9\% di Afrika dan Asia dan yang paling tinggi di Amerika Latin dan Caribbean yang mencapai angka 26\% (Jeyabalan, 2013) .

$\mathrm{Di}$ Indonesia, pre eklampsia penyebab kematian ibu yang tinggi sebesar 24\% (Depkes
RI 2012) . Banyak faktor yang menyebabkan meningkatnya insiden pre eklampsia pada ibu hamil . Faktor risiko yang dapat meningkatkan insiden pre eklampsia antara lain molahidatidosa, nulipara, usia kurang dari 20 tahun atau lebih dari 35 tahun, janin lebih dari satu, multipara, hipertensi kronis, diabetes mellitus atau penyakit ginjal. Pre eklampsia/eklampsia dipengaruhi juga oleh paritas, genetik dan faktor lingkungan (Cunningham, 2014)

Kejadian pre eklampsia dapat di pengaruhi oleh paritas, ras, faktor genetik dan lingkungan. Dalam kehamilan dengan pre eklampsia lebih umum terjadi pada primigravida, sedangkan pada multigravida lebih berhubungan dengan penyakit hipertesi kronis, diabetes milletus dan penyakit ginjal (Gafur,2012) . Pre eklampsia hampir secara eksklusif merupakan penyakit pada nulipara . Terdapat pada wanita usia subur dengan umur ekstrim, biasanya pada wanita umur $>35$ tahun atau remaja belasan tahun (Mochtar, 2007)

Usia sangatlah berpengaruh pada kehamilan maupun dalam persalinan. Pada wanita dibawah 20 tahun dan diatas umur 35 tahun tidak dianjurkan untuk hamil maupun melahirkan. Dikarenakan pada usia tersebut memiliki risiko tinggi yaitu salah satunya terjadi keguguran bahkan juga bisa mengakibatkan kematian pada ibu maupun bayinya (Gunawan $S, 2010)$. Pre eklampsia dari 2,601 ibu hamil ditemukan sebanyak $58,1 \%$ pada usia $<35$ tahun (Qiu et.al 2009) .

Hasil penelitian Karima (2015), untuk paritas didapatkan hasil ibu primigravida memiliki peluang sebesar 1,318 kali lebih besar mengalami Pre Eklampsia Berat (PEB) dibanding dengan ibu multigravida nilai peluang Odd Ratio (OR) dengan Confidence Interval 95\% sebesar 1,318 yang artinya Hasil uji chi-square didapatkan nilai $p=0,1$ yang artinya tidak terdapat hubungan antara paritas dengan kejadian PEB . Hasil penelitian Rozikhan 
(2007), menunjukan dari hasil uji chi-square diperoleh bahwa tidak ada perbedaan yang bermakna antara ibu hamil yang pendidikannya SD/SLTP dengan terjadinya pre eklampsia berat $(p=1,00)$. Dari nilai OR $(95 \%$ C I $)=1,0(0,56$ 1,79)

Hasil studi pendahuluan yang dilakukan, didapatkan jumlah kasus PEB di RSIA dr. Djoko Pramono Karawang Jawa Barat Tahun 2019 sebanyak 8,27\%, (Data Rekam Medik RSIA dr. Djoko Pramono Karawang Tahun 2019). Oleh karena itu penulis ingin meneliti Determinan kejadian Pre eklampsia di RSIA dr. Djoko Pramono Karawang Jawa Barat 2019.

\section{METODE}

Pada penelitian ini digunakan data sekunder didapatkan dari rekam medik dan catatan persalinan dalam buku besar, data diambil dari bulan Januari sampai Desember 2019. Rancangan penelitian cross sectional. Populasi dalam penelitian ini adalah seluruh ibu yang bersalin di RSIA dr. Djoko Pramono Karawang Jawa Barat Tahun 2019 yaitu sebanyak 2343 orang. Teknik pengambilan sampel dengan menggunakan teknik Systematic Random Sampling, sampel sebanyak 376 responden dengan memenuhi kriteria inklusi dan ekslusi yang telah ditetapkan. Instrumen penelitian menggunakan check list. Teknik analisis data dalam penelitian ini adalag analisis univariate, bivariate dan multivariate.

\section{HASIL}

Hasil penelitian menunjukkan bahwa sebesar 296 (78,7\%) tidak mengalami kejadian pre eklampsia pada ibu bersalin dan sebanyak 80 (21,3\%) mengalami kejadian pre eklampsia pada ibu bersalin. Dari 80 responden yang mengalami pre eklampsia didapatkan 36 responden (45\%) mengalami pre eklampsia ringan dan 44 responden (55\%) mengalami pre eklampsia berat.(Tabel 1 )

http://ejournal.urindo.ac.id/index.php/kesehatan
Hasil penelitian didapatkan responden usia tidak berisiko sebesar 238 (63,3\%) dan usia berisiko sebesar 138 (36,7\%), dengan rentang usia termuda yaitu 17 tahun, rentang usia tertua 48 tahun, usia terbanyak 27 tahun dan rata-rata usia bersalin 28 tahun. Responden primipara sebesar $98(26,1 \%)$ dan responden multipara sebesar 278 (73,9\%), dengan paritas terkecil dan terbanyak adalah primipara dan jumlah paritas tertinggi adalah 5 . responden yang berpendidikan tinggi sebesar 293 (77,9\%) dan berpendidikan rendah sebesar 83 (22,1\%), dengan pendidikan terendah SMP, pendidikan tertinggi S1 dan mayoritas responden berpendidikan SMA. Responden yang tidak bekerja 274 (72,9\%) dan yang bekerja sebesar $102(27,1 \%)$, dengan mayoritas jenis pekerjaan pada responden bekerja sebagai buruh pabrik. Responden dengan tidak ada riwayat hipertensi sebesar 309 (82,2\%) dan memiliki riwayat hipertensi sebesar 67 (17,8\%), kemudian responden dengan tidak ada riwayat DM sebesar $338(89,9 \%)$ dan ada riwayat DM sebesar 38 (10,1\%). Pada variabel pemeriksaan ibu bersalin yang memiliki riwayat hipertensi angka kejadian Pre eklampsia lebih tinggi yaitu sebesar 41 (61,2\%), sedangkan pada ibu bersalin yang tidak ada riwayat hipertensi sebesar 39 (12,6\%) yang mengalami kejadian pre eklampsia. Hasil uji statistik di peroleh $p$ value $=0,000<\alpha(0,05)$ hal tersebut menunjukkan bahwa ada hubungan antara usia dengan kejadian pre eklampsia pada ibu bersalin. Hasil analisis didapat nilai $\mathrm{OR}=10,9$ artinya ibu bersalin memiliki riwayat hipertensi mempunyai peluang/kesempatan untuk mengalami pre eklampsia sebesar 10,9 kali lebih tinggi dibandingkan ibu bersalin yang tidak memiliki riwayat hipertensiANC, yang melakukan ANC teratur sebesar 314 (83,5\%) dan yang tidak ANC teratur sebesar 62 (16,5\%), ibu yang ANC nya tidak teratur terbanyak tidak melakukan kunjungan pertama di Trimester I yaitu K1. (Tabel 2). 
Ibu bersalin yang usianya berisiko angka kejadian Pre eklampsia lebih tinggi yaitu sebesar $59(42,8 \%)$, sedangkan pada ibu bersalin yang usianya tidak berisiko sebesar 21 (8,8\%) yang mengalami kejadian pre eklampsia. Hasil uji statistik di peroleh $p$ value $=0,000<\alpha(0,05)$ hal tersebut menunjukkan bahwa ada hubungan antara usia dengan kejadian pre eklampsia pada ibu bersalin. Hasil analisis didapat nilai $\mathrm{OR}=7,7$ artinya ibu bersalin yang usianya berisiko mempunyai peluang/kesempatan untuk mengalami pre eklampsia sebesar 7,7 kali lebih tinggi dibandingkan ibu bersalin yang usianya tidak berisiko.

Pada multipara angka kejadian pre eklampsia sebesar $54(19,4 \%)$, sedangkan pada primipara sebesar $26(26,6 \%)$ yang mengalami kejadian pre eklampsia. Hasil uji statistik di peroleh $p$ value $=0,141<\alpha(0,05)$ hal tersebut menunjukkan bahwa tidak ada hubungan yang signifikan antara paritas dengan kejadian pre eklampsia pada ibu bersalin.

Ibu bersalin yang pendidikannya rendah angka kejadian Pre eklampsia lebih tinggi yaitu sebesar 31 (30,4\%), sedangkan pada ibu bersalin yang pendidikannya tinggi sebesar 39 $(13,3 \%)$ yang mengalami kejadian pre eklampsia. Hasil uji statistik di peroleh $\mathrm{p}$ value $=$ $0,000<\alpha(0,05)$ hal tersebut menunjukkan bahwa ada hubungan antara pendidikan dengan kejadian pre eklampsia pada ibu bersalin. Hasil analisis didapat nilai $\mathrm{OR}=6,3$ artinya ibu bersalin yang pendidikan rendah mempunyai peluang/ kesempatan untuk mengalami pre eklampsia sebesar 6,3 kali lebih tinggi dibandingkan ibu bersalin yang pendidikan tinggi.

Ibu bersalin yang bekerja angka kejadian Pre eklampsia lebih tinggi yaitu sebesar 59 (42,8\%), sedangkan pada ibu bersalin yang tidak bekerja sebesar 49 (17,9 \%) yang mengalami kejadian pre eklampsia. Hasil uji statistik di peroleh $p$ value $=0,009<\alpha(0,05)$ hal tersebut menunjukkan bahwa ada hubungan antara pekerjaan dengan kejadian pre eklampsia pada ibu bersalin. Hasil analisis didapat nilai $O R=2,0$ artinya ibu bersalin yang bekerja mempunyai peluang/kesempatan untuk mengalami pre eklampsia sebesar 2 kali lebih tinggi dibandingkan ibu bersalin yang tidak bekerja.

Ibu bersalin yang memiliki riwayat hipertensi angka kejadian Pre eklampsia lebih tinggi yaitu sebesar 41 (61,2\%), sedangkan pada ibu bersalin yang tidak ada riwayat hipertensi sebesar 39 (12,6\%) yang mengalami kejadian pre eklampsia. Hasil uji statistik di peroleh $p$ value $=0,000<\alpha(0,05)$ hal tersebut menunjukkan bahwa ada hubungan antara riwayat hipertensi dengan kejadian pre eklampsia pada ibu bersalin. Hasil analisis didapat nilai $\mathrm{OR}=10,9$ artinya ibu bersalin memiliki riwayat hipertensi mempunyai peluang/kesempatan untuk mengalami pre eklampsia sebesar 10,9 kali lebih tinggi dibandingkan ibu bersalin yang tidak memiliki riwayat hipertensi.

Ibu bersalin yang memiliki riwayat DM angka kejadian Pre eklampsia lebih tinggi yaitu sebesar 19 (50\%), sedangkan pada ibu bersalin yang tidak ada riwayat DM sebesar 61 (18\%) yang mengalami kejadian pre eklampsia. Hasil uji statistik di peroleh $\mathrm{p}$ value $=0,000<\alpha(0,05)$ hal tersebut menunjukkan bahwa ada hubungan antara riwayat DM dengan kejadian pre eklampsia pada ibu bersalin. Hasil analisis didapat nilai $O R=4,5$ artinya ibu bersalin yang ada riwayat DM mempunyai peluang/ kesempatan untuk mengalami pre eklamsia sebesar 4,5 kali lebih tinggi dibandingkan ibu bersalin yang tidak ada riwayat DM.

Ibu bersalin yang tidak teratur pemeriksaan ANC angka kejadian Pre eklampsia lebih tinggi yaitu sebesar $38(61,3)$, sedangkan pada ibu bersalin yang teratur pemeriksaan ANC sebesar $42(13,4 \%)$ yang mengalami kejadian pre eklampsia. Hasil uji statistik di peroleh $p$ 
value $=0,000<\alpha(0,05)$. Hal tersebut menunjukkan bahwa ada hubungan antara pemeriksaan ANC dengan kejadian pre eklampsia pada ibu bersalin. Hasil analisis didapat nilai $\mathrm{OR}=10,2$ artinya ibu bersalin yang kunjungan ANC nya tidak teratur mempunyai peluang/kesempatan untuk mengalami pre eklamsia sebesar 10,2 kali lebih tinggi dibandingkan ibu bersalin yang kunjungan ANC nya teratur.

Variabel dominan yang berhubungan dengan kejadian pre eklampsia dalam penelitian ini adalah pemeriksaan ANC Hasil analisis didapatkan Odds Ratio (OR) dari variabel pemeriksaan ANC adalah 15,6 artinya ibu bersalin yang tidak teratur melakukan pemeriksaan ANC mempunyai risiko untuk terjadi pre eklampsia 15,6 kali lebih besar dibandingkan ibu bersalin yang melakukan pemeriksaan ANC secara teratur. Jadi variabel yang dominan berhubungan dengan kejadian pre eklampsia pada ibu bersalin adalah pemeriksaan ANC.
Tabel 1

Kejadian Pre eklampsia pada ibu bersalin

$\begin{array}{lcc}\text { Kejadian } & \text { Jumlah } & \% \\ \text { Preeklamsi } & & \\ \text { Tidak Pre eklampsia } & 296 & 78,7 \\ \text { Pre eklampsi } & 80 & 21,3 \\ \text { Jumlah } & 376 & 100\end{array}$

Tabel 2

Variabel independen kejadian pre eklampsia pada ibu bersalin

\begin{tabular}{llrl}
\hline No & Variabel & Jumlah & $\%$ \\
\hline 1 & Usia & & \\
& Tidak berisiko & 238 & 63,3 \\
& Berisiko & 138 & 36,7 \\
2 & Paritas & & \\
\end{tabular}

\begin{tabular}{|c|c|c|c|}
\hline & Primipara & 98 & 26,1 \\
\hline \multirow{3}{*}{3} & Multipara & 278 & 73,9 \\
\hline & Pendidikan & & \\
\hline & Tinggi & 293 & 77,9 \\
\hline \multirow{3}{*}{4} & Rendah & 83 & 22,1 \\
\hline & Pekerjaan & & \\
\hline & Tidak bekerja & 274 & 72,9 \\
\hline \multirow{4}{*}{5} & Bekerja & 102 & 27,1 \\
\hline & Riwayat Hipertensi & & \\
\hline & Tidak ada & 309 & 82,2 \\
\hline & Ada & 67 & 17,8 \\
\hline \multirow[t]{3}{*}{6} & Riwayat DM & & \\
\hline & Tidak ada & 338 & 89,9 \\
\hline & Ada & 38 & 10,1 \\
\hline \multirow[t]{3}{*}{7} & Pemeriksaan ANC & & \\
\hline & Teratur & 314 & 83,5 \\
\hline & Tidak teratur & 62 & 16,5 \\
\hline
\end{tabular}

Primipara $\quad 98 \quad 26,1$

3 Pultipara 
Tabel 3

Kejadian pre eklampsia dengan usia, paritas, pendidikan, pekerjaan, riwayat hipertensi, riwayat DM dan pemeriksaan ANC pada ibu bersalin

\begin{tabular}{|c|c|c|c|c|c|c|c|c|}
\hline \multirow{3}{*}{ Variabel } & \multicolumn{4}{|c|}{ Kejadian Preeklamsi } & & & \multirow{3}{*}{ P Value } & \multirow{3}{*}{$\begin{array}{c}\text { OR } \\
(95 \% \mathrm{Cl})\end{array}$} \\
\hline & \multicolumn{2}{|c|}{$\begin{array}{c}\text { Pre } \\
\text { eklampsia }\end{array}$} & \multicolumn{2}{|c|}{$\begin{array}{l}\text { Tidak Pre } \\
\text { eklampsia }\end{array}$} & \multicolumn{2}{|c|}{ Total } & & \\
\hline & $\mathbf{n}$ & $\%$ & $\mathbf{n}$ & $\%$ & $\mathbf{n}$ & $\%$ & & \\
\hline \multicolumn{9}{|l|}{ Usia } \\
\hline Berisiko & 59 & 42,8 & 79 & 57,2 & 138 & 100 & \multirow[b]{2}{*}{0,000} & \\
\hline Tidak berisiko & 21 & 8,8 & 217 & 91,2 & 238 & 100 & & $(4,40-13,5)$ \\
\hline \multicolumn{9}{|l|}{ Paritas } \\
\hline Multipara & 54 & 19,4 & 224 & 80,6 & 278 & 100 & \multirow[t]{2}{*}{0,141} & 0,6 \\
\hline Primipara & 26 & 26,5 & 72 & 73,5 & 98 & 100 & & $(0,39-1,14)$ \\
\hline \multicolumn{9}{|l|}{ Pendidikan } \\
\hline Rendah & 41 & 49,4 & 42 & 50,6 & 83 & 100 & \multirow[t]{2}{*}{0,000} & 6,3 \\
\hline Tinggi & 39 & 13,3 & 254 & 86,7 & 293 & 100 & & $(3,68-10,9)$ \\
\hline \multicolumn{9}{|l|}{ Pekerjaan } \\
\hline Bekerja & 31 & 30,4 & 71 & 69,6 & 102 & & \multirow[t]{2}{*}{0,009} & 2,0 \\
\hline Tidak bekerja & 49 & 17,9 & 225 & 82,1 & 274 & 100 & & $(1,18-3,38)$ \\
\hline \multicolumn{9}{|c|}{ Riwayat Hipertensi } \\
\hline Ada & 41 & 61,2 & 26 & 38,8 & 67 & 100 & \multirow[t]{2}{*}{0,000} & 10,9 \\
\hline Tidak ada & 39 & 12,6 & 270 & 87,4 & 309 & 100 & & $(6,02-19,7)$ \\
\hline \multicolumn{9}{|l|}{ Riwayat DM } \\
\hline Ada & 19 & 50,0 & 19 & 50,0 & 38 & 100 & \multirow[t]{2}{*}{0,000} & 4,5 \\
\hline Tidak ada & 61 & 18,0 & 277 & 82,0 & 338 & 100 & & $(2,26-9,08)$ \\
\hline \multicolumn{9}{|c|}{ Pemeriksaan ANC } \\
\hline Tidak teratur & 38 & 61,3 & 24 & 38,7 & 62 & 100 & \multirow[t]{2}{*}{0,000} & 10,2 \\
\hline Teratur & 42 & 13,4 & 272 & 86,6 & 314 & 100 & & $(5,59-18,7)$ \\
\hline
\end{tabular}

Tabel 4

Permodelan Multivariat Akhir

\begin{tabular}{lllll}
\hline No & Variabel & B & $\begin{array}{l}\text { P } \\
\text { value }\end{array}$ & OR \\
\hline 1 & Usia & 2,489 & 0,000 & 12,055 \\
2 & Pendidikan & 2.180 & 0,000 & 8,848 \\
3 & Pekerjaan & 1,007 & 0,014 & 2,737 \\
4 & Riwayat & 2,311 & 0,000 & 10,086 \\
& Hipertensi & & & \\
5 & Riwayat DM & 1,530 & 0,008 & 4,619 \\
6 & Pemeriksaan & 2,751 & 0,000 & 15,659 \\
& ANC & & & \\
\hline
\end{tabular}

Berdasarkan hasil penelitian yang dilakukan terhadap 376 responden diperoleh hasil ibu bersalin yang tidak mengalami pre eklampsia sebesar $296(78,7 \%)$, sedangkan ibu bersalin yang mengalami pre eklampsia sebesar 80 $(21,3 \%)$, hal ini dipengaruhi oleh variabel umur, pendidikan, pekerjaan, riwayat hipertensi, riwayat DM dan kunjungan ANC), di Indonesia angka kejadian pre eklampsia diperkirakan sebesar 3-10\% dari seluruh kehamilan.

Hasil penelitian ini sejalan dengan penelitian yang dilakukan oleh Ika Mardiatul, dkk (2018) mengenai hubungan Pre Eklampsia Berat (PEB) pada ibu bersalin dengan asfiksia neonatorum 
di RSUD Dr. H Moch Ansari Saleh Banjarmasin dengan sampel 100, yang mengalami PEB sebanyak $55 \%$.

Menurut Cunningham et al., (2005) mendefinisikan pre eklampsia adalah sindrom kehamilan spesifik yang ditandai dengan penurunan perfusi organ secara sekunder hingga terjadinya aktivasi vasospasme dan endotel .

Pre eklampsia mempunyai gambaran klinik bervariasi dan komplikasinya sangat berbahaya pada saat kehamilan, persalinan dan masa nifas. Gambaran klinis yang utama dan harus terpenuhi adalah terdapatnya hipertensi dan proteinuria, karena organ target yang utama terpengaruhi adalah ginjal (glomerular endoteliosis) . Patogenesisnya sangat kompleks, dipengaruhi oleh genetik, imunologi, dan interaksi faktor lingkungan (Pribadi, A., et al, 2015) .

Preeklampsi merupakan penyulit kehamilan yang akut dan dapat terjadi antenatal, intranatal dan postpartum (Prawirohardjo, 2010) pre-eklampsia juga merupakan kondisi khusus dalam kehamilan, ditandai dengan peningkatan tekanan (TD), bengkak pada kaki, tangan sampai muka dan pengeluaran protein urin . Bisa kejang-kejang (Eklampsi) dan gagal organ ganda pada ibu, sementara komplikasi pada janin meliputi restriksi pertumbuhan abrosio plasenta (Capman, 2006)

Heffner dan Schust (2009) berpendapat bahwa faktor risiko yang dapat mempengaruhi terjadinya pre eklampsia adalah primigravida, diabetes, kehamilan kembar, hipertensi yang telah dialami sebelum kehamilan, riwayat pre eklampsia pada kehamilan sebelumnya, adanya riwayat pre eklampsia dalam keluarga, kehamilan dengan mola hidatidosa dan adanya kelainan pembekuan darah .

Menurut Wibowo dan Rachimhadhi, 2006 penanganan pada pre eklampsia hanya dapat dilakukan secara simtomatis karena etiologi pre eklampsia dan faktor-faktor apa dalam kehamilan yang menyebabkannya, belum diketahui .
Hasil penelitian didapatkan ada hubungan antara usia dengan kejadian pre eklampsia. Hasil penelitian ini sejalan dengan penelitian yang dilakukan oleh Dien Gusta Anggraini, dkk (2014) mengenai Faktor Risiko Kejadian Pre eklampsia pada ibu hamil di RSUP DR. M.Djamil Padang Tahun 2014 yang hasilnya adalah ada hubungan antara umur dengan kejadian pre eklampsia dengan nilai $p=0,006$, namun tidak sejalan dengan penelitian Novita Lusiana (2014) mengenai faktor-faktor yang berhubungan dengan kejadian pre eklampsia pada ibu bersalin di R. Camar II RSUD Arifin Achmad Prov. Riau yang hasilnya adalah bahwa tidak ada hubungan antara faktor umur dengan kejadian preeklampsia $(p=0,114)$.

Hal tersebut sesuai dengan Gunawan $S$ (2010), bahwa usia yang tidak beresiko untuk hamil 20-35 tahun, pada usia tersebut alat reproduksi wanita telah berkembang dan berfungsi secara maksimal. Sebaliknya pada wanita dengan usia $<20$ tahun atau >35 tahun kurang baik untuk hamil maupun melahirkan karena kehamilan pada usia ini memiliki risiko tinggi terjadinya keguguran atau kegagalan persalinan, bahkan bisa menyebabkan kematian . Pada wanita dengan usia $<20$ tahun perkembangan organ-organ reproduksi dan fungsi fisiologinya belum optimal serta belum tercapainya emosi dan kejiwaan yang cukup matang dan akhirnya akan mempengaruhi janin yang dikandungnya hal ini akan meningkatkan terjadinya gangguan kehamilan dalam bentuk preeklampsia dan eklampsia akibat adanya gangguan sel endotel, selain itu preeklampsia juga terjadi pada usia >35 tahun diduga akibat hipertensi yang diperberat oleh kehamilan. Oleh karena itu insiden hipertensi meningkat diatas 35 tahun .

Penelitian yang dilakukan oleh Langelo, dkk (2013), menunjukan bahwa wanita umur $<20$ tahun dan >35 tahun memiliki risiko 3,37 kali dibandingkan wanita umur 20-35 tahun. Selain itu, hasil penelitian Asrianti (2009)menyimpulkan bahwa umur ibu hamil $<20$ tahun dan >35 tahun berisiko 3,144 kali mengalami preeklampsia, penelitian Salim 
(2005) juga menyebutkan usia ibu hamil $<20$ tahun atau $\geq 35$ tahun berisiko 3,615 kali lebih besar untuk mengalami preeklampsia, serta hasil penelitian Ferida (2007) menyimpulkan, ibu hamil dengan usia yang sama berisiko 3,659 kali lebih besar untuk mengalami pre eklampsia .

Pada umur kurang dari 20 tahun, rahim dan panggul seringkali belum tumbuh mencapai ukuran dewasa . Akibatnya ibu hamil pada umur itu berisiko mengalami penyulit pada kehamilannya dikarenakan belum matangnya alat reproduksinya . Keadaan tersebut diperparah jika ada tekanan (stress) psikologi saat kehamilan (Sukaesih, 2012).

Pada umur 35 tahun atau lebih, kesehatan ibu sudah menurun akibatnya ibu hamil pada usia itu mempunyai kemungkinan lebih besar untuk mempunyai anak cacat, persalinan lama dan perdarahan. Disamping itu, pada wanita usia>35 tahun sering terjadi kekakuan pada bibir rahim sehingga menimbulkan perdarahan hebat yang bila tidak segera diatasi dapat menyebabkan kematian ibu (Armagustini, 2010)

Hasil penelitian didapatkan tidak ada hubungan antara paritas dengan kejadian pre eklampsia. Paritas merupakan jumlah kehamilan yang menghasilkan janin yang lahir hidup, bukan jumlah janin yang dilahirkan (Bobak, I,2004) . Persalinan yang berulangulang akan mempunyai banyak risiko terhadap kehamilan, semakin tinggi paritas semakin tinggi kematian maternal . Hal tersebut dikarenakan pada setiap kehamilan terjadi peregangan rahim, jika kehamilan berlangsung terus menerus maka rahim akan semakin melemah sehingga dikhawatirkan akan terjadi gangguan pada saat kehamilan, persalinan, dan nifas (Sukaesih, 2012) . Paritas dikatakan tinggi bila seorang wanita melahirkan anak ke empat atau lebih, paritas tinggi mempunyai angka kematian maternal lebih tinggi, lebih tinggi paritas lebih tinggi pula kematian maternal. Wanita yang telah banyak melahirkan $\geq 3$ orang rentan terhadap komplikasi yang serius, bahaya pada masa kehamilan salah satunya adalah preeklampsia dimana pada paritas yang tinggi aliran darah akan menurun ke plasenta yang menyebabkan ganguan plasenta sehingga terjadi gangguan pertumbuhan janin karena kekurangan oksigenasi (Prawirohardjo, 2008) .

Resiko pada paritas tinggi dapat dikurangi atau dicegah dengan keluarga berencana (Prawirohardjo, 2002) . Paritas adalah seorang wanita yang sudah pernah melahirkan bayi yang dapat hidup (Syaifuddin, 2011) . Wanita yang telah banyak melahirkan $\geq 3$ orang rentan terhadap komplikasi yang serius, bahaya pada masa kehamilan salah satunya adalah preeklampsi dimana pada paritas yang tinggi aliran darah akan menurun keplasenta yang menyebabkan ganguan plasenta sehingga terjadi gangguan pertumbuhan janin karena kekurangan oksigenasi (Prawirohardjo, 2008)

Menurut peneliti paritas tidak mempengaruhi kejadian pre eklampsia dikarenakan semakin banyak jumlah anak yang dilahirkan maka semakin banyak mendapat pengalaman dalam menjaga dan merawat proses kehamilan, dan juga kondisi sekarang ini dimana akses untuk mendapatkan informasi mengenai komplikasi kehamilan mudah didapatkan, sehingga ibu dengan paritas tinggi lebih siap lagi untuk menghadapi kehamilannya

Hasil penelitian didapatkan ada hubungan antara pendidikan dengan kejadian pre eklampsia. Hasil penelitian Supriandono (2001) menyebutkan bahwa 93,9\% penderita pre eklampsia berpendidikan kurang dari 12 tahun . Menurut hasil penelitian Nuryani, dkk (2012) menunjukan bahwa ibu yang mengalami pre eklampsia $63,1 \%$ memiliki pendidikan kurang dan ibu yang memiliki pendidikan rendah 2,190 akan mengalami kejadiaan pre eklampsia dari pada ibu yang memiliki pendidikan tinggi, namun hasil penelitian ini tidak sejalan dengan penelitian yang dilakukan oleh Dien Gusta, dkk (2014) dengan hasil tidak ada hubungan antara pendidikan dengan kejadian pre eklampsia .

Pendidikan adalah suatu usaha mengembangkan kepribadian dan kemampuan didalam dan diluar sekolah dan berlangsung 
seumur hidup. Pendidikan mempengaruhi proses belajar, semakin tinggi pendidikan seseorang makin mudah orang tersebut untuk menerima informasi . Seseorang yang memiliki pendidikan tinggi maka akan cenderung untuk mendapatkan informasi, baik dari orang lain maupun dari media massa. Semakin banyak informasi yang masuk semakin banyak pula pengetahuan yang didapat tentang kesehatan.Oleh karena itu, Pendidikan sangat erat hubungannya dengan pengetahuan seseorang. Pengetahuan seseorang tentang suatu objek mengandung dua aspek yaitu aspek positif dan negatif. Kedua aspek inilah yang akan menentukan sikap dan perilaku seseorang. (Sulistiyani, 2013) .

Pendidikan seseorang berhubungan dengan kesempatan dalam menyerap informasi mengenai pencegahan dan faktor-faktor risiko preeklampsia. Tetapi pendidikan ini akan dipengaruhi oleh seberapa besar motivasi, atau dukungan lingkungan seseorang untuk menerapkan pencegahan dan faktor risiko pre eklampsia/eklampsia (Djannah, 2010) .

Semakin banyak pendidikan yang didapat seseorang, maka kedewasaannya semakin matang, mereka dengan mudah untuk menerima dan memahami suatu informasi yang positif . Kaitannya dengan masalah kesehatan, dari buku safe motherhood menyebutkan bahwa wanita yang mempunyai pendidikan lebih tinggi cenderung lebih memperhatikan kesehatan dirinya . Tingkat pendidikan sangat mempengaruhi bagaimana seseorang untuk bertindak dan mencari penyebab serta solusi dalam hidupnya. Orang yang berpendidikan tinggi biasanya akan bertindak lebih rasional . Oleh karena itu orang yang berpendidikan akan lebih mudah menerima gagasan baru. (Notoatmodjo, 2003) .

Hasil penelitian didapatkan ada hubungan antara pekerjaan dengan kejadian pre eclampsia. Hasil penelitian ini sejalan dengan penelitian yang dilakukan oleh Katmini, dkk (2018) mengenai faktor-faktor yang berhubungan dengan kejadian pre eklampsia pada ibu hamil di Kabupaten Kediri jawa Timur, yang hasilnya adalah ada hubungan antara pekerjaan dengan kejadian pre eklampsia, namun hasil penelitian ini tidak sejalan dengan peneltian yang dilakukan oleh Yulia Nur dkk (2017) mengenai hubungan stress dan pekerjaan dengan pre eklampsia di wilayah kabupaten Semarang yang hasilnya adalah tidak ada hubungan anatara pekerjaan dengan kejadian pre eklampsia .

Faktor pekerjaan ibu dapat mempengaruhi terjadinya risiko pre eklampsia/eklampsia. Wanita yang bekerja diluar rumah memiliki risiko lebih tinggi mengalami pre eklampsia dibandingkan dengan ibu rumah tangga. Pekerjaan dikaitkan dengan adanya aktifitas fisik dan stress yang merupakan faktor risiko terjadinya pre eklampsia (Indriani, 2012) ..

Hasil penelitian didaptkan ada hubungan antara riwayat hipertensi dengan kejadian pre eclampsia. Ibu yang pernah mengalami komplikasi pada waktu kehamilan, persalinan dan nifas sebelumnya akan menghadapi risiko tinggi pada kehamilan dan persalinan berikutnya. Menurut Djaja dan Suwandono (2006), ibu yang mengalami komplikasi pada kehamilan terdahulu berisiko 14 kali mengalami komplikasi pada kehamilan berikutnya dibandingkan ibu yang tidak mengalami komplikasi pada kehamilan dahulu .

Menurut penelitian Diana, dkk (2014), diketahui bahwa ibu yang mempunyai riwayat komplikasi obstetrik berisiko untuk mengalami komplikasi obstetri ibu 5,41 kali lebih besar daripada ibu yang tidak mempunyai riwayat komplikasi obstetri sebelumnya .

Riwayat obstetrik mencakup konsepsi sebelumnya, ada tidaknya infertilitas dan hasil akhir yang tidak normal termasuk keguguran, kehamilan diluar kandungan/Kehamilan Ektopik Terganggu (KET), kematian janin berulang, dan riwayat reproduksi anggota keluarga . Masalah konsepsi pada kehamilan sebelumnya merupakan penentu terkuat hilangnya janin pada kehamilan berikutnya (Sukaesih, 2012) . Peningkatan risiko preeklampsia/eklampsia dapat terjadi pada ibu yang memiliki riwayat hipertensi kronik, diabetes dan adanya riwayat pre eklampsia/eklampsia sebelumnya . 
Riwayat hipertensi adalah ibu yang pernah mengalami hipertensi sebelum hamil atau sebelum umur kehamilan 20 minggu . Ibu yang mempunyai riwayat hipertensi berisiko lebih besar mengalami preeklampsia, serta meningkatkan morbiditas dan mortalitas maternal dan neonatal lebih tinggi. (Cuningham, 2006) . Normalnya dalam kehamilan arteri spiralis dalam rahim akan melebar dari pembuluh darah muskuler berdinding tebal, menjadi pembuluh darah yang tipis dengan diameter yang jauh lebih besar, perubahan ini meningkatkan kapasitas pembuluh darah sehingga mereka bisa menerima peningkatan volume darah pada kehamilan. Pada pasien dengan preeklampsia terjadi penurunan perfusi plasenta dan hipoksia, Ishkemi plasenta diperkirakan menyebabkan disfungsi sel endotel dengan merangsang pelepasan substansi yang toksik terhadap endotel . Kelainan ini menyebabkan perfusi jaringan yang buruk pada semua organ, meningkatkan resistensi perifer dan tekanan darah, serta meningkatkan pemeabilitas sel endotel, menyebabkan kebocoran cairan dan protein intra vaskelar serta akhirnya menyebabkan volume plasma berkurang (Lowdermilk dkk, 2013) .

Hasil penelitian didaptkan ada hubungan antara riwayat DM dengan kejadian pre eklampsia. Hasil penelitian ini sejalan dengan peneltian yang dilakukan oleh Dien Gusti, dkk (2014) dengan hasil ada hubungan antara riwayat DM dengan kejadian Pre eklampsia .

Riwayat penyakit kronis seperti hipertensi dan Diabetes Mellitus dapat menyebabkan kesehatan dan pertumbuhan janin terganggu dan dapat terjadi penyulit selama kehamilan . Apabila ibu hamil memiliki hipertensi maka risiko terjadinya lahir mati, retardasi pertumbuhan janin, dan pre eklampsi akan menjadi lebih besar, sedangkan ibu yang memiliki penyakit Diabetes Mellitus (DM) akan meningkatkan mortalitas perinatal sebesar 3$5 \%$, sedangkan kejadian anomali kongenital berisiko lebih tinggi 6-12\% dibandingkan dengan ibu hamil tanpa DM 2-3 \% (Sukaesih, 2012) .
Hasil penelitian didapatkan ada hubungan antara pemeriksaan ANC dengan kejadian pre eklampsia. Antenatal Care (ANC) adalah pelayanan kesehatan yang diberikan oleh tenaga kesehatan untuk ibu selama kehamilannya dan dilaksanakan sesuai dengan standar pelayanan yang ditetapkan dalam Standar Pelayanan Kebidanan (SPK) . Pelayanan Antenatal yang diberikan sesuai dengan Standar Asuhan Kebidanan sangat mempengaruhi kondisi ibu dan janin, baik pada saat kehamilan, persalinan, maupun masa nifas (0-42 hari) dan neonatus (0-28 hari) . Faktor risiko juga dapat terdeteksi sehingga penanganan dan rujukan dapat dilakukan sedini mungkin (Pritasari dkk, 2012) .

Pemeriksaan antenatal yang teratur dan teliti dapat menemukan tanda-tanda dini preeklampsia, untuk itu harus dilakukan penanganan semestinya . Karena preeklampsia biasanya tidak mengemukakan keluhan dan jarang memperhatikan tandatanda preeklampsia yang sudah terjadi, maka deteksi dini keadaan ini memerlukan pengamatan yang cermat dengan masa-masa interval yang tepat (Cunningham, 2010). Perawatan antenatal umumnya dianggap metode yang efektif untuk meningkatkan hasil kehamilan, tetapi efektivitas spesifik program perawatan antenatal sebagai sarana untuk mengurangi kematian bayi dalam kelompok sosio ekonomi kurang beruntung dan rentan perempuan belum dievaluasi secara mendalam (Jenifer, 2016) .

$$
\text { Ibu hamil yang melakukan }
$$
kunjungan ANC lengkap dapat meningkatkan kewaspadaan dan menjaga kondisi kesehatan kehamilan dengan cara mengatur aktivitas fisik dan memperhatikan kebutuhan energi san zat gizi selama masa kehamilan, sehingga kemungkinan terjadinya gangguan kesehatan pada ibu dan janin sangat kecil (Kemenkes, 2010) 


\section{SIMPULAN}

1. Ibu bersalin yang mengalami kejadian pre eklampsia yaitu $21,3 \%$ terdiri dari $45 \%$ mengalami pre eklampsia ringan dan 55\% mengalami pre eklampsia berat.

2. Ada hubungan antara usia, pendidikan, pekerjaan, riwayat hipertensi, riwayat DM dan pemeriksaan ANC dengan kejadian pre eklampsi, dan tidak ada hubungan anatara paritas dengan kejadian pre eklampsia

3. Faktor dominan yang berhubungan dengan kejadian pre eklampsia adalah pemeriksaan ANC.

\section{DAFTAR PUSTAKA}

Armagustini, Yetti. Determinan Kejadian Komplikasi Persalinan Di Indonesia (Analisis Data Sekunder Survei Demografi dan Kesehatan Indonesia Tahun 2007). Skripsi. Program Pascasarjana Fakultas Kesehatan Masyarakat Universitas Indonesia; 2010.

Asrianti T. 2009. Faktor Risiko Kejadian Preeklampsia pada Ibu Melahirkan di RSIA Siti Fatimah Makassar.Skripsi.Universitas Hasanuddin.Makassar.

Arun Jeyabalan. 2013. Epidemiology of preeclampsia: Impact of obesity. Department of Obstetrics, Gynecology and Reproductive Sciences.

American College Obstetricians and Gynecologysts (ACOG), 2013, "Clasification Hypertensive Disorders", in : Hypertension inPregnancy, p: 13-14

Brown, M, Magee, L, Kenny, L, Karumanchi, S, McCarthy, F, Saito, S, Hall, D, Warren, C, Adoyi, G, Ishaku, S 2018, 'The Hypertensive Disorders of Pregnancy: ISSHP Classification, Diagnosis \& Management Recommendations for International Practice', Pregnancy Hypertension, vol 13, pp 29, 310
Bobak. (2004). Buku Ajar Keperawatan Maternitas. (R. Komalasari, Ed.) (ke 4). Jakarta: Buku Kedokteran EGC.

BKKBN, 2008, Badan kependudukan dan Keluarga Berencana Nasional, http://depkes.go.id, 31 Maret 2020.

Challis JR, Sloboda DM, Alfaidy N, Lye SJ, Gibb W, Patel FA, Whittle WL, Newnham JP2002, 'Prostaglandins and Mechanisms of Preterm Birth',Reproduction, vol 124(1), pp 1, 17

Chau, K, Hennessy, A, Makris, A 2017, 'Placental Growth Factor and Pre-Eclampsia', J Hum Hypertens, vol 31(12), pp 782, 786

Cunningham, et al. 2014. Obstetri WilliamsEdisi 23. Jakarta: EGC.

Cunningham, F. G., et al. 2005. Hipertensi dalam kehamilan dalam Obstetri Williams Edisi 21 Volume 2. Jakarta: Penerbit Buku Kedokteran EGC.

Cunningham, G.F. et al. (2010). Williams Obstetrics (23rded.). USA: Mc-Graw Hill.

Djannah, S. N, et al,. 2010.Gambaran epidemiologi kejadian preeklampsia/ eklampsia di rsu pku muhammadiyah yogyakarta tahun 2007-2009. Buletin penelirian sistem kesehatan. 13: 378385

Djaja, Sarimawar, dan Suwandono, Agus., 2006. Determinan Kematian Maternal di Indonesia. Jakarta : Yayasan Bina Pustaka.

Departemen Kesehatan RI. 2012. Profil Kesehatan Indonesia. Jakarta:Depkes RI

Diana. dkk,. 2014. Analisis Faktor-Faktor yang Berhubungan dengan Komplikasi Obstetri Ibu dan Bayi di Kecamatan Parongpong Kabupaten Bandung Barat. Jurnal Universitas Padjadjaran 
Dien Gusta Anggraini, dkk. Faktor Risiko Kejadian Pre eklampsia pada ibu hamil di RSUP DR. M.Djamil Padang Tahun 2014.

Ferida, Dewi,R.,S. 2007. Faktor -Faktor yang Mempengaruhi Kejadian Preeklampsia-Eklampsia di RSUD Syekh Yusuf Kabupaten Gowa. Skripsi.Universitas Hasanuddin Makassar

Gafur.A, Nurdin.A, Rahmadhany.S, dan Rahim.M.R.(2012). Hubungan Antara Primigravida dengan Preeklampsia.

Gunawan, S. (2010). Reproduksi Kehamilan dan Persalinan. Jakarta: CV Graha

Heffner L.J., Schust D.J., 2008, At a Glance, Sistem Reproduksi Edisi Kedua, Jakarta: Penerbit Buku Kedokteran EGC pp.54-5.

Indriani, N. (2012). Analisi Faktor-Faktor yang berhubungan dengan Preeklamsia/ eklamsia pada Ibu Bersalin di Rumah Sakit Umum Daerah Kardinah kota tegal tahun 2011. Skripsi. Depok: Fakultas Kesehatan Masyarakat Program Studi Kebidanan Komunitas. Universitas Indonesia.

Ika Mardiatul, dkk (2018) Hubungan Preeklampsia Berat (PEB) pada ibu bersalin dengan asfiksia Neonatorum di RSUD Dr. H. Moch Ansari Saleh Banjarmasin Tahun 2018.

John JH, Ziebland S, Yudkin P., et al (2002). Effect of fruits and vegetable consumptions on plasma antioxidant concentrations and blood pressure: a randomized controlled trial.Lancet. 359:1969

Jennifer et al. Pre-eclampsia: Pathophysiology, Diagnosis, andManagement. Vasc Health Risk Manag. 2011; 7:467-74
Kementerian Kesehatan RI (2013). Riset Kesehatan Dasar 2013. Jakarta : Kementerian Kesehatan RI.

Kementerian Kesehatan RI (2015). Rencana Strategis Kementerian Kesehatan 20152019. Jakarta : Kementerian Kesehatan RI.

Karima.2015. Hubungan Faktor Risiko dengan kejadian Pre-eklamsia Berat di RSUP Dr. M . Djamil Padang. Jurnal Kesehatan Andalas.

Katmini, dkk (2018). Faktor-faktor yang berhubungan dengan kejadian pre eklampsia pada ibu hamil di Kabupaten Kediri Jawa Timur Tahun 2018.

Kasriatun, dkk. Faktor Risiko Internal dan Eksternal Pre eklampsia di Wilayah Kab. Pati Prov. Ja-Teng Tahun 2018.

Karlsson, T. et al., 2015. Lower vitamin D status in obese compared with normal-weight women despite higher vitamin D intake in early pregnancy. Clinical Nutrition Journal, 34(5), pp. 892-898

Lockhart Anita dan Saputra Lyndon. 2014. Asuhan Kebidanan Fisiologis dan Patologis. Tanggerang: BINARUPA AKSARA Publisher

Langelo, Wahyuni, dkk. 2012. Faktor Risiko Kejadian Preeklampsia Di RSKD Ibu dan Anak Siti Fatimah Makassar tahun 20112012. [Disertasi Ilmiah]. Makassar: Fakultas Kesehatan Masyarakat Universitas Hasanuddin.

Lilis Fatmawati, dkk. Pengaruh status kesehatan ibu terhadap derajat Pre eklampsia/eklamsia di Kab. Gesik Tahun 2017.

Lisa Astuti, dkk (2019). Hubungan kepatuhan melakukan ANC dengan kejadian Pre 
eklampsia di Puskesmas Pamulang Tangerang Selatan Tahun 2019.

Lowdermilk Deitra Leonard. (2013). Keperawatan Maternitas. Jakarta : Elsevier Mosby.

Manuaba I, B, G. 2007. Pengantar Kuliah Obstetri. Jakarta : EGC. pp. 401-31

Manuaba I. B. G. (2010). Pengantar Kuliah Obstetri. Jakarta : EGC

Morgan, Geri dan Hamilton Carole. 2009. Obstetri \& Ginekologi. Jakarta : EGC

Mochtar, Rustam. 2007. Sinopsis Obstetri.Jakarta : EGC

Mackenzie RM, Sandrim VC \&Carty DM., et al.(2012): Endhotelial FOS expression and preeclampsia. BJOG119 (13) : 1564

McCarthy., Meine.1992. A Framework for Analyzing the Determinants of Maternal Mortality. Studies in Family Planning Vol. 23, No. 1 (Jan. -Feb., 1992), pp. 23-33. http://www.jstor.org/stable/1966825dia kses pada 12 Maret 2020

Mufdlilah. 2013. Antenatal Care Fokus. Yogyakarta : Nuha Medika

NotoatmodjoS (2005). Metodologi penelitian kesehatan. Ed ke-3, Jakarta: Rineka Cipta.

Notoatmodjo, S. 2010. Metodologi Penelitian Kesehatan.Jakarta: Rineka Cipta.

Notoatmodjo, S. (2012). Promosi Kesehatan dan Perilaku kesehatan. Jakarta: Rineka Cipta.

Novita Lusiana (2014). Faktor-faktor yang berhubungan dengan kejadian pre eklampsia pada ibu bersalin di R. Camar II RSUD Arifin Achmad Prov. Riau Tahun 2014.
Nuryani, Ade dkk, 2013, Hubungan Pola Makan, Sosial Ekonomi, Antenatal Care dan Karakteristik Ibu Hamil dengan Kasus Preeklampsia di Kota Makassar, (Online), Volume II, No. 2, hal 104-112, diakses 23 Mei 2020, (http://450-684-1-SM(2).pdf).

Profil RSUD X Kerawang Jawa Barat Tahun 2019

Pritasari, dkk. 2012. Petunjuk Kerja Pelayanan Antenatal Terpadu, Persalinan, dan Paska Persalinan Terpadu. Maternal and Child Health Integrated Program USAID. Halaman 1-2

Perkumpulan Obstetri dan Ginekologilndonesia. (2014). Pedoman Nasional Pelayanan Kedokteran Indonesia: Diagnosis dan Tata Laksana Preeklampsia. Diakses tanggal 28 Maret 2020 dari http://pogi.or.id/publish/hotnews/

Pribadi, A., Mose, J.C., Anwar, A.D.(2015). Kehamilan Risiko Tinggi. Jakarta: CV Sagung Seto

Qiu Chunfang, et all. 2009. Preeclampsia Risk in Relation to Maternal Mood and Anxiety Disorders Diagnosed Before or During Pregnancy. American Journal of Hypertension (AJH), Volume 22 ; issue 4 $>$ 397-402.

Raghupathy R. 2013. Cytokines as Key Players in the Pathophysiology of Preeclampsia. Journal Medical Principles and Practice, 22 (23), 8-19

Redman C.W, Sargent I.L, Taylor R.N, 2014, Immunology of Abnormal Pregnancy and Preeklampsia", In :Taylor RN, Roberts JM, Cunningham FG (eds): Chesley's Hypertensive Disorders in Pregnancy, 4th ed. Amsterdam, Academic Press, p:161-79 
Royston, E., dan Armstrong, S.1994. Pencegahan Kematian Ibu Hamil. Jakarta: Bina Rupa Aksara.

Rozikhan. 2007. Faktor - Faktor R isiko Terjadinya Pre-eklampsia Berat di Rumah Sakit Dr. H. Soewondo Kendal. Semarang : UNDIP (Thesis)

Saifuddin, A. B., 2006. Buku Panduan Praktis Pelayanan Kesehatan Maternal dan neonatal. Jakarta: YBSP, pp:37-9.

Sulistiyani, Dwi. 2013. Gambaran Tingkat Pengetahuan Ibu Hamil Mengenai Perubahan Fisik Saat Kehamilan di BPM Anik Suroso Mojosongo Surakarta Tahun 2013. Karya Tulis Ilmiah. Surakarta : STIKes Kusuma Husada

Salim, Adriani, R. 2005. Faktor Risiko Kejadian Preeklampsia di Rumah Sakit Ibu dan Anak St. Fatimah Makassar. Skripsi. Universitas Hasanuddin Makassar

Sukaesih, Sri. (2012). Faktor-faktor yang Berhubungan dengan Pengetahuan lbu Hamil mengenai tanda Bahaya dalam Kehamilan di Puskesmas Tegal Selatan Kota tegal Tahun 2012. Skripsi.Program Sarjana Kesehatan Masyarakat Universitas Indonesia.

Supriandono, A., 2001. Faktor risiko terjadinya Preeklampsia Berat di RSUP Dr. Sardjito Yogyakarta.

SDKI. (2016). Pendekatan Tentang Angka Kematian Ibu dan Balita, Sehingga Hasil Survei Jauh Lebih Lengkap dan Sempurna, http://sirusa.bps.go.id diakses 3 Maret 2020

Pritasari, Kirana. (2012). Kebijakan dan Strategi Percepatan Sasaran 5 MDGs Dan Pelayananan Kesehatan Yang mendukung Revitalisasi KB. Rakernas Pembangunan KB Tahun 2012. http://online-journal.unja.ac.id. diakses tanggal 5 Maret 2020

POGI,2014. Pelatihan Klinik Asuhan Persalinan Normal. Jakarta: JNPK-KR DEPKES RI.

Prawirohardjo, S. 2007. Pre-eklampsia dan Eklampsia dalam Ilmu Kebidanan. Jakarta : yayasan Bina Pustaka. pp : 280 - 301.

Wibowo., Rachimhadi. 2006. Proteinuria dalam Ilmu Penyakit Dalam Jilid 1 edisi 5. Jakarta: Penerbit FKUI, pp:519-23

World Health Organization. Global Health Observatory (GHO): Maternal and Reproductive Health. 2013; Available from:

http://www.who.int/gho/maternal heal th/en/.

Ward K; Taylor RN. Genetic Factors in the Etiology of of Preeclampsia[Internet]. Fourth Edition. Vol. 25, Cancer Research Chelsey's Hypertensive Disorders in Pregnancy. Elsevier Inc.; 2014. h.1320-1326. [cited 2020 Mar 30]. Available from: http://dx.doi.org/10.1016/B978-0-12407866-6.00004-3

Yuyun Setyorini, dkk (2012). Faktor-faktor yang mempengaruhi kejadian PEB pada pasien rawat inap di Ruang ICU Tahun 2012.

Yudia Gustri, dkk (2015). Determinan kejadian Pre eklampsia pada ibu hamil di RSUP DR. M. Hoesin Padang Tahun 2015.

Yulia Nur, dkk (2017). Hubungan stress dan pekerjaan dengan pre eklampsia di wilayah kabupaten Semarang tahun 2017.

Zhang C, Williams MA, King IB., et al. (2002). Vitamin $C$ and the risk of preeclampsia-results from dietary questionnaire and plasma assay: Epidemiology. 13: 382 